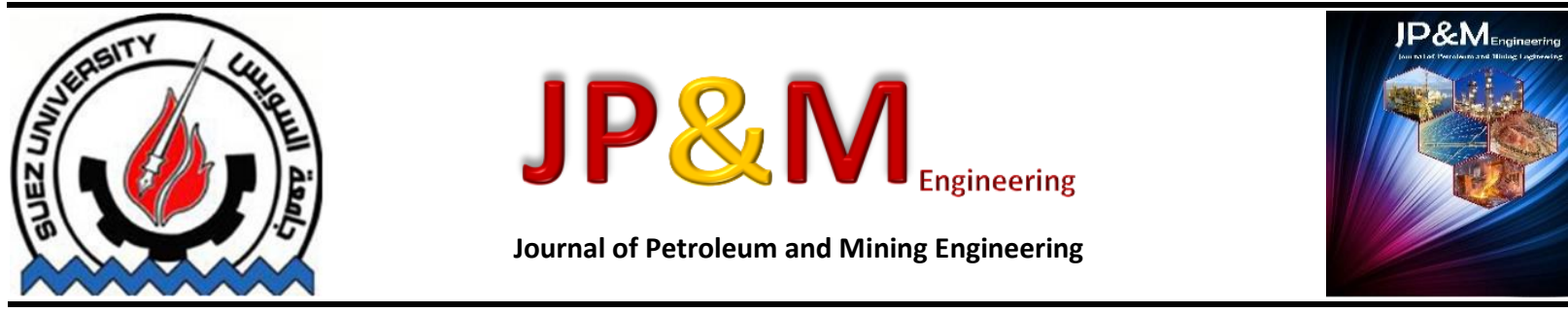

\title{
Characterization of the Campanian-Maastrichtian Sudr Chalk, Gabal El Bruk, North Sinai, Egypt
}

\author{
Hatem F. Hassan ${ }^{* a}$ and Mohamed O. Abouelresh ${ }^{b}$ \\ ${ }^{a}$ Faculty of Science, Port-Said University, Port-Said, Egypt \\ ${ }^{b}$ Center of Integrative Petroleum Research, King Fahd University of Petroleum \& Minerals, Dhahran, 31261, Saudi Arabia \\ *Corresponding author e-mail: hatem99_eg@yahoo.com
}

\section{Keywords}

Sudr Chalk; Upper Cretaceous; North Sinai; Planktonic; Benthonic; Total Organic Carbon (TOC); Source Rock.

\section{Introduction}

The Upper Cretaceous sea level encroachment over North Sinai was marked by shallow marine to basin sediments. Among these sediments is the Sudr Chalk which deposited generally within deep marine conditions due to the presence of synclines formed as a result of the Syrian-arc system of Krenkel [1]. It is consequently represented by persisting facies almost all over North Sinai such as chalk, chalky limestone or even argillaceous limestone. It is dated CampanianMaastrichtian as well documented and accepted by many authors [2-11].

Numerous papers in the literature have dealt with the Sudr Chalk in many aspects among them, 12-20.Cherif et al. [21] suggested continuous open marine sedimentation prevailed from the Late Campanian to the Late Maastrichtian based upon the foraminiferal content, and Shahin [22] assigned a middle neritic environment to the Sudr Chalk.

Although the Upper Cretaceous source and reservoir rocks of the Western Desert and Nile Delta have been intensively studied and analyzed, very little

work has been published concerning the hydrocarbon potential of these rocks in the northern Sinai. However, the tectonic history of northern Sinai provides favorable conditions for deposition of several seals, source and reservoir rocks as well as different types of structural traps [23]. The general hydrocarbon potential of different rock units in North Sinai has been studied by several authors [2426]. However, attention to hydrocarbon potential of the abundant upper Cretaceous rocks is a must to develop a complete petroleum system scheme in the northern Sinai.

The purpose of this work is to establish the depositional model of the Sudr Chalk using lithology, microfacies and biostratigraphy. An additional purpose is to evaluate the total organic carbon (TOC) richness of the Sudr Chalk that may contribute to the potential of subsurface petroleum system at both onshore and offshore north Sinai. 


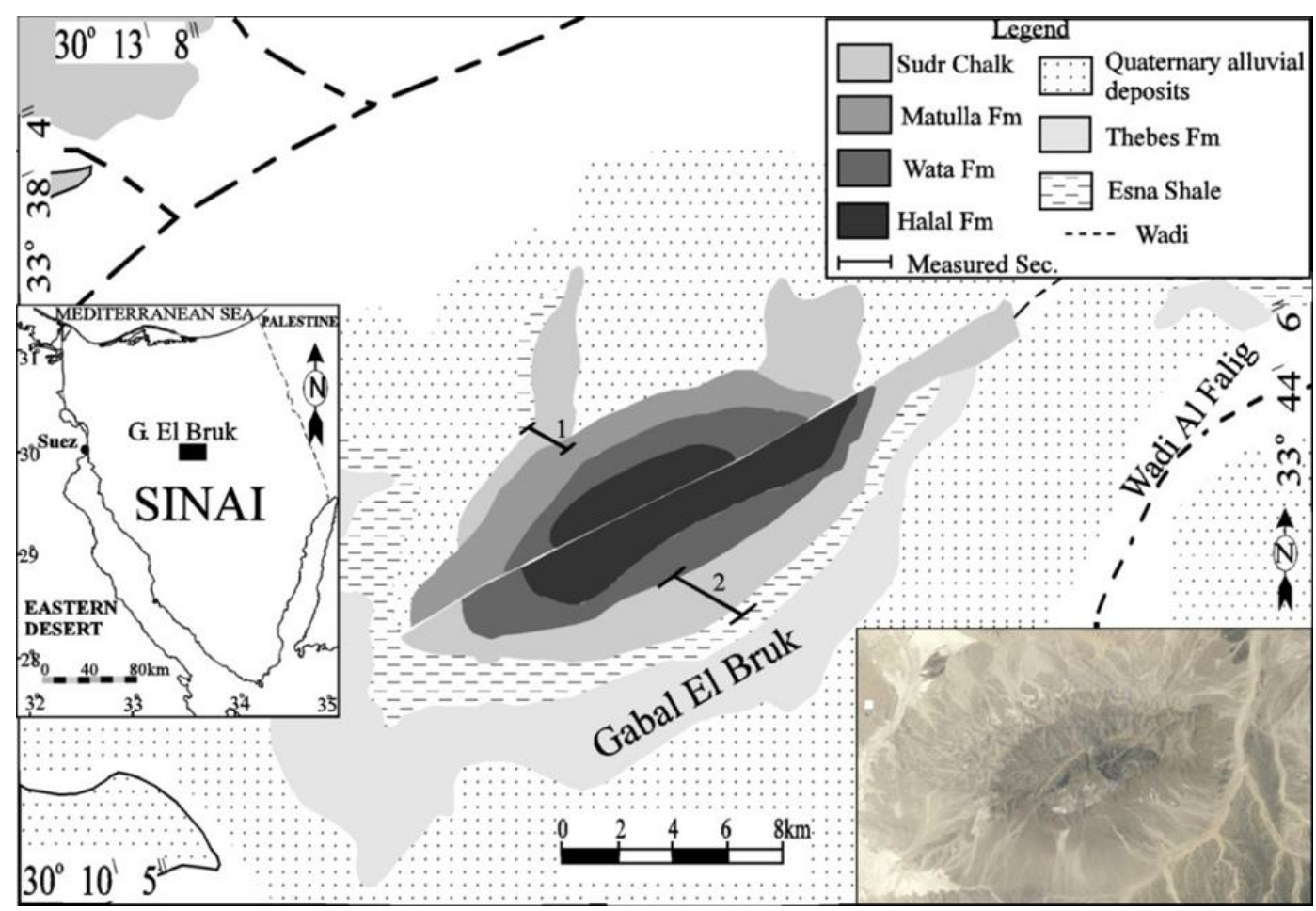

Figure 1 Geological map and Satellite image of the studied Sudr chalk of Gabal El-Burk, North Sinai (modified after the geological survey of Egypt, 1993)

Gabal El-Bruk is located in the southern part of North Sinai at latitude $30^{\circ} 12^{\prime} \mathrm{N}$ and longitude $33^{\circ}$ $44^{\prime} \mathrm{E}$ (Fig. 1). It is accessible through the main paved road from El-Hasana to Nakhl in North Sinai. The studied section gently dips $\left(\approx 5^{\circ}\right)$ toward the NE and displays conformable relations between the underlying Matulla Formation and the overlying Esna Shale. It attains a total thickness of $50.8 \mathrm{~m}$ as investigated through two profiles 1 and 2, Fig. 1.

\section{Materials and Methods}

In order to pursue these objectives, the G. El Bruk surface section has been studied, measured and sampled in detail. Eighty two samples representing the Sudr Chalk were collected from two different locations (Fig. 1) and subjected to micropaleontological analysis for their faunal content, biostratigraphic zonation and paleobathymetry. About 10 grams from the chalk, chalky limestone and argillaceous limestone were soaked in hydrogen peroxide $\mathrm{H}$ ? $\mathrm{O} 2(10 \%)$, washed and then sieved through a $0.63 \mathrm{~mm}$ sieve. The residue was fractionated into three grades by sets of sieves 60, 120 and 320 meshes for easier handling. The foraminifera are picked up by a special needle and brushes, then examined using a standard binocular microscope (Table 1).

The microfacies analysis was studied through 12 thin sections representing the different bed geometry and lithology.The classification of carbonate rocks according to depositional textures [27] is adopted here in addition to the encountered Standard Microfacies (SMF) types of Wilson [28] and Flügel [29].

Forty four samples were selected for TOC measuring by the ignition loss method, an inexpensive and reliable technique [30]. Following the technique adopted by Ben-Dor \& Banin [31] which is summarized as follows. The rock samples were ground to pass a $0.2 \mathrm{~mm}$ sieve (Table 1). Five grams of air dried samples were kept in $30 \mathrm{ml}$ crucibles and dried at $105^{\circ} \mathrm{C}$ overnight, cooled in a desiccator, and weighted. The samples were then ignited at $400^{\circ} \mathrm{C}$ for 4 hours in a muffle furnace. Samples were transferred after $4 \mathrm{hrs}$ ignition period to a desiccator until it is cooled down and again weighted. The loss on ignition was then calculated using the following formula.

TOC $=\left(\mathrm{W}_{1}-\mathrm{W}_{2}\right) / \mathrm{W}_{1} \mathrm{X} 100$

Where $W_{1}=$ Oven dry rock weight $(\mathrm{gm})$ dried at $105^{\circ} \mathrm{C}$

$\mathrm{W}_{2}=$ rock weight after ignition at $400^{\circ} \mathrm{C}$

The total carbon measured was assumed to equate the organic carbon

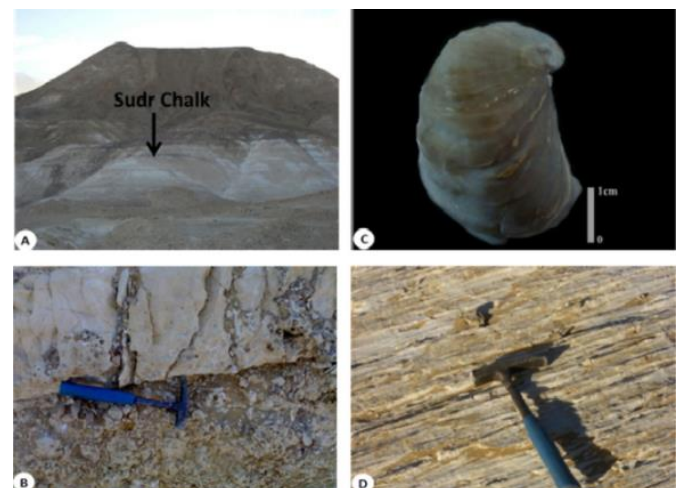

Figure 2 a) Field photo a) Field photo shows the Sudr Chalk at G. El-Bruk overlain by Paleocene Esna Shale. B) Field photo shows the massively bedded, brown dirty argillaceous chalky limestone of Markha member. C) 'Pycnodonta (Phygraea) vesicularis (Lamarck) a distinct index macrofossils representing the Sudr Chalk. D) Field photo shows thinly well bedded snow chalk of Abu Zenima Member, G. El-Bruk. 


\section{Lithostratigraphy}

The Sudr Chalk recognized by Ghorab $[32,2]$ is a sequence of snow-white chalk, chalky limestone and argillaceous limestone (100-130 m thick), which sometimes yield small pectinids with intermittent chert bands. Cherif et al. [21] determined a late Campanian-Maastrichtian age, whereas Kerdany and Cherif [33] assigned it to the Maastrichtian. On the other hand, the Sudr Chalk is coeval with the upper part of the Sayyarim and Ghareb Formations in the Israeli nomenclature. They were originally attributed to the Campanian-Maastrichtian [18].

In the study area, a sequence of chalky limestone overlain by purely chalk facies and argillaceous limestone is characteristic of the Sudr Chalk in Gabal El Bruk area. It is mainly distributed in the lowlands around the anticlinal structures of Gabal El Bruk with sub-horizontal attitude (Fig. 2a).

Ghorab 32] subdivided the Sudr Chalk into two members, the Markha Member and the Abu Zenima Member. This subdivision will be followed in this work.

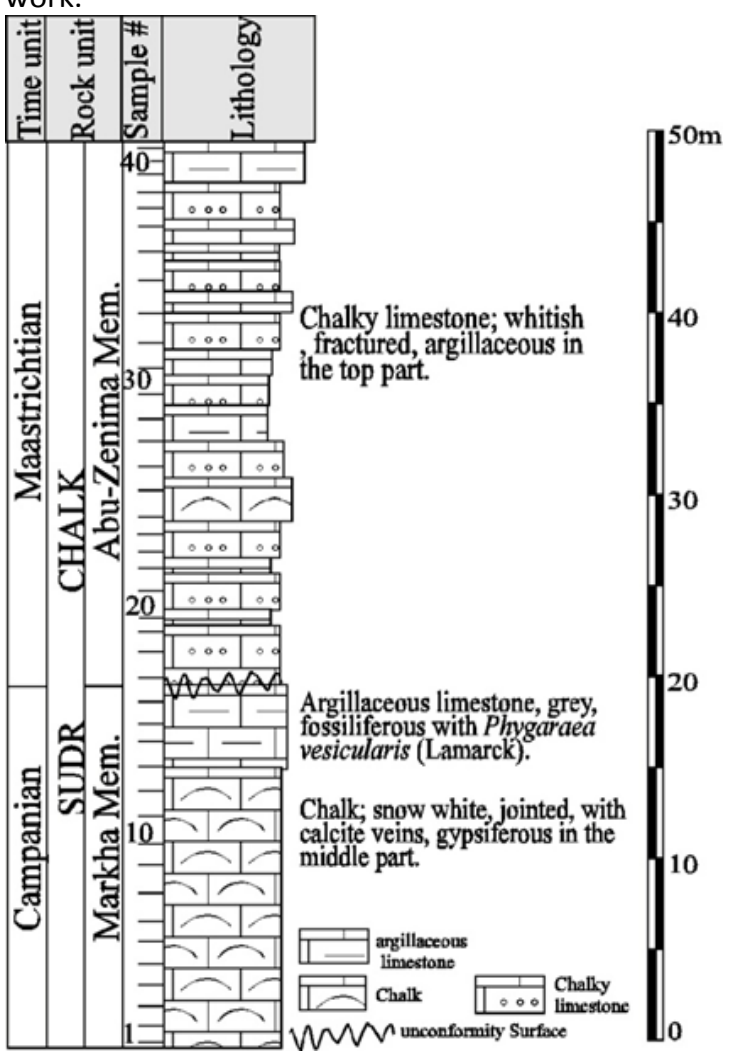

Figure 3 Lithostratigraphic section of the Sudr Chalk at Gabal El-Bruk area, North Sinai, Egypt.

\section{A. Markha Member}

In it's type section at Wadi Markha, this member consists of massive, poorly-bedded, brown, cherty, chalky limestones with numerous banks of Phygraea vesicularis (Lamarck), Ghorab [2] gave a Campanian age to this member.

In the study area, the Markha Member is composed of snow white, massive chalk with calcite veins which grade into brown, dirty, argillaceous chalky limestones at the top part (Fig. 2b), and are characterized by Phygraea vesicularis (Fig. 2c) in the middle part. The horizon containing Phygraea vesicularis is a good marker in the field to distinguish the Markha Member of Campanian age from the overlying Abu Zenima Member. However, it should not be used to determine the contacts between the Markha and overlying Abu Zenima members. This was pointed out by [34, 35 and 20] who did not regard Phygraea vesicularis as providing avaluable biostratigraphic tool to distinguish between Campanian and Maastrichtian, as misinterpreted by many authors [e.g. 36 and 37].

The Markha member conformably overlies the Matulla Formation. It has $20 \mathrm{~m}$ thickness at G. ElBruk (Fig. 3).

\section{Abu Zenima Member}

The Abu Zenima Member consists of wellbedded, yellowish white chalky limestones, becoming argillaceous in the upper part. In its type locality, Ghorab[2] assigned a Maastrichtian age to this member.

In the study area, the Abu Zenima Member consists mainly of thinly well-bedded chalk and chalky limestones, gradually changing into argillaceous limestones at the top and turned into shale (Fig. 2d). It measures $30.8 \mathrm{~m}$ at Gabal El Bruk. The Abu Zenima Member conformably overlies the Markha Member and is conformably overlain by the Paleocene Esna Shale (Fig. 3).

\section{Microfacies}

The microscopic investigation of 12 thin sections representing the Sudr Chalk at Gabal El Bruk revealed the presence of two microfacies association:-

Foraminiferal micrite (wackstone)

This microfacies association is recorded in the upper part of the Abu- Zenima member, it is represented by chalky limestone. Petrographically, it is composed essentially of foraminiferal tests which make $30-40 \%$ of the total rock content, and few scattered fragments of foraminiferal tests as well as few shell fragments of ostracods (Fig. 4a).

All the above mentioned components are embedded in a micritic matrix(Fig. 4a). The foraminiferal tests are mainly planktonic represented by globotruncanids and heterohelicids (Fig. 4b). Small numbers of benthonic foraminifera are also encountered. The foraminiferal tests are filled with sparite while the wall structure is still micrite (Fig. 4b). The micritic matrix is homogenous microcrystalline partially recrystallized into microsparite due to aggrading neomorphism [38]. This microfacies is proper of pelagic wackstones deposited in basin margin or deep shelf margin, SMF3 and FZ1 [28 and 29]. The planktonic foraminiferal content as well as the less abundance of benthonic species indicates that the sediments of this microfacies were commonly deposited below the wave base at depths ranging between 200 to $300 \mathrm{~m}$. Fossiliferous mudstone (Mudstone)

This microfacies is determined by the petrographic analysis of thin sections representing the lower and middle part of the Markha member. 

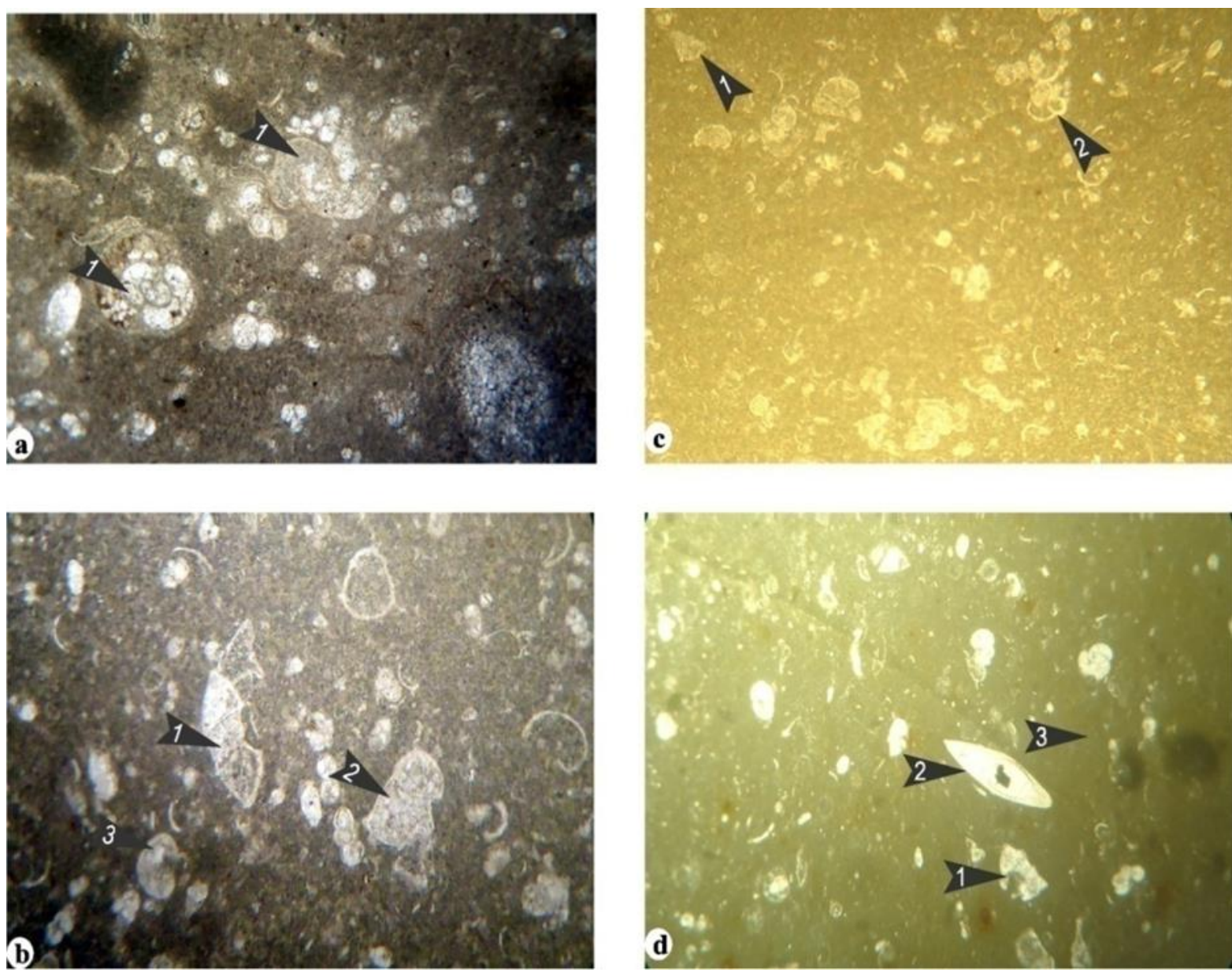

Figure 4 a) Photomicrograph shows benthic foraminiferal tests (arrow1) embedded in micrite groundmass (Foraminiferal micrite microfacies, P.P.L. X 50). B) Several tests of planktonic foraminifera (Globotruncana, arrow 1 and Heterohelix, arrow 2) in addition benthic form (arrow 2) filled with neomorphosed sparite, (Foraminiferal micrite microfacies, P.P.L. X 50).C) Rare fossils scattered in mud-lime matrix globotruncanids (arrow 1) and rugoglobigerina (arrow 2); Fossiliferous mudstone microfacies, C.N X 30. D) Globotruncanids (arrow 1) as well as ostracod carapace (arrow 2) filled with neomorphosed sparite and embedded in green mud-lime matrix (arrow 3), Fossiliferous mudstone microfacies, C.N X 35 .

Petrographically; it consists of traces of foraminiferal tests less than $10 \%$ of the rock content and patches of microsparite scattered in microcrystalline calcitic matrix "micrite" (Fig. 4c). The chambers of the foraminiferal tests are partially filled with sparite.The presence of scattered microsparite patches and partial filling of chambers of foraminiferal tests with sparite (Fig. 4d) indictes neomorphic recrystallization as diagenetic process.

This microfacies is similar to the pelagic wackstone microfacies which probably deposited in the basin margin SMF3 and FZ1[28 and 29] but due to the scarcity of their fauna (benthonic and planktonic) it is most probably deposited shallower than the precedding microfacies (foraminiferal micrite) in the middle neritic environment (100$50 \mathrm{~m})$.

\section{Biostratigraphy}

The biostratigraphic analysis of the current work is based mainly on planktonic foraminifera where the Campanian-Maastrichtian Sudr Chalk sediments yield rich and diversified species. In this context, our biostratigraphic zonation is relying mainly on the latest classification scheme of Li \& Keller [39-41].

Identification of forty-five planktonic species and subspecies in regards to the FO (First Occurrence) and LO (Last Occurrence) of the species, lead to identification of ten biostratigraphic zones (Table 2) as studied before by Hassan \& Nassif [42].

The planktonic biozones CF13 and CF12 were established to define the Campanian based upon the FO of Golobotruncanita elevata and Contusotruncana patelliformis respectively. Whereas the Maastrichtian biozones begin with CF8 with notable discontinuity in regarding to the Campanian biozones and continued up to the late Maastrichtian CF2 zones, based upon the nominate taxa as defined according to Li \& Keller [39-40] and Li et al. [41]. As indicated in table (2) it is observed that the biozones thicknesses decrease upward from CF13 up to CF2 which represent a complete evolutionary lineage from Campanian up to Maastrichtian, except for the absence of late Campanian biozones (CF11 to CF9). This gap indicates that after the deposition of CF8 the Sudr Chalk was subaerially exposed as a paleostructural high due to the tectonic uplift of the Syrian arc fold system. The same conclusion was reached by Farouk \& Faris [43] in the area around G. Libni, North Sinai.

It is important to denote that evidences of tectonic uplift are also recorded in several localities in Sinai and it falls within the foraminiferal zones $G$. ventricosa and Gansserina gansseri zone (CF8) as 
recorded by Lüniing et al. [20]. In Gabal Somar, west central Sinai, uplift may have begun earlier as

Table 1 Biostratigraphic zonation of the CampanianMaastrichtian Sudr Chalk based upon planktonic foraminifera (Hassan \& Nassif, 2010)

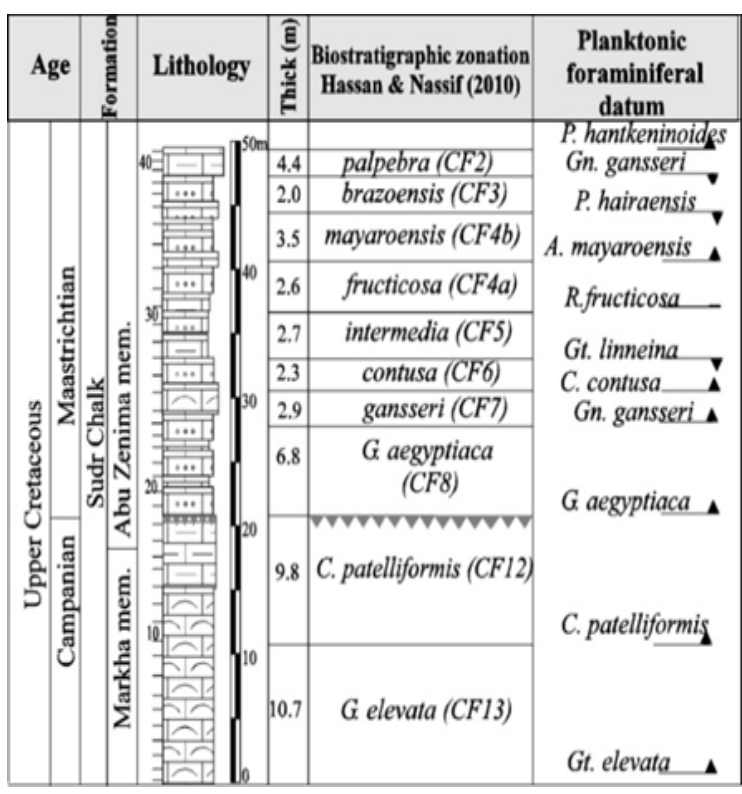

indicated by the absence of the entire Campanian succession [10], where the magnitude of hiatus was greater as indicated by the absence of the Upper Campanian up to Early Eocene (Ypresian) succession [44].

\section{Planktonic Foraminiferal Analysis}

Using the foraminiferal assemblages as paleoenvironmental proxies follows basically three main approaches: direct comparison with recent microfaunas 45-47], morphofunctional analysis or morphogroups [48-51]. The last one is concerned with the comparison of the distribution of foraminifera in different ancient models. Several models for the distribution of the microfaunal assemblages have been established [52-60]. In some of these models, the foraminiferal assemblage zones are attributed to specific paleobathymetric levels.

\section{Qualitative and semiquantitative analysis}

Qualitative and semiquantitative analyses of the Upper Cretaceous foraminiferal assemblages in Egypt had been undertaken by several authors $[8,22,47$, 61-64].

The paleoecological and paleobathymetrical reconstruction of the Campanian- Maastrichtian Sudr Chalk is based essentially on qualitative (foraminiferal groups, Midway and Velasco-type fauna). The term velasco-type "fauna" (VF) was suggested by Berggren and Aubert (1975) for a lower continental slope and abyssal plain fauna, which counterpart the Midway-Type "fauna" (MF) typically represent the continental shelf .According to distribution models of microfauna and semiquantitative analysis (\% of Planktics (PI \%) and PI./b ratio) of the foraminiferal assemblages (Fig. 6).The following is a detailed discussion of the paleoecological interpretation and the depositional environments of the studied Sudr Chalk based upon foraminiferal data.

\section{Markha Member}

The Campanian Markha member consists only of two biozones; CF13 and CF12.The lithology of this member is essentially chalk to chalky limestone that gradually changed upward to argillaceous limestone close to the Campanian/ Maastrichtian (Zones related to Middle Campanian ?) boundary. The abundance of Midway type fauna is diagnostically higher than Velasco type fauna indicating that the Campanian Sudr Chalk was deposited most probably on the continental shelf (Fig. 5). On the other hand, the statistical parameters (Table 1 ) show that, the average PI.\% ranges from 32.1 to $60.3 \%$ in CF13 whereas the P:B ratio ranges from 0.4 to $1.5 \%$. However, the CF12 zone shows higher PI. \% than CF13, which reaches $76.9 \%$. The intermediate ratio of planktonic foraminifera (Table 2) in this member characterizes the middle neritic $(50-100 \mathrm{~m}$ depth) zone [65, 66 and 67] and reflects a shallow middle shelf environment.

\section{Abu Zenima Member}

Biostratigraphically, the Maastrichtian zones overlie disconformably the Campanian zones as indicated by the absence of latest Campanian zones CF11-CF9, although no evidences of a break occur in the lithological succession.

The whole Abu Zenima member consists of chalk, chalky limestone, and argillaceous limestone. Interestingly, the uppermost zone (CF1) of Maastrichtian age is extended upwards into the Paleocene Esna shale. The benthonic fauna show an intermediate value between Velasco-type fauna and Midway type fauna (Fig. 5), indicating an increase in water depth from continental shelf during the Campanian to lower slope during the Maastrichtian time.

The statistical data of the PI. \% varies from $25 \%$ (lowest value) at CF7 to $86.5 \%$ (highest value) at CF2 indicating a progressively water depth's deepening upward (Fig. 6). It is also obvious that the P:B ratio varies in accordance with $\mathrm{PI}$ \%, both in CF3 and CF2, which reflect higher ratios than any other zones.

\section{Depositional Environment and Paleobathymetry}

The depositional environments of the studied Sudr chalk remains open to discussion due to the widespread occurrences of the Upper Cretaceous sediments all over Egypt. These sediments are characterized by different microfacies associations from one place to another as well as the great diversity of both the benthonic and planktonic foraminiferal proportion. One of the most helpful approaches to understand the depositional environment and paleobathymetryis the development of the facies model based upon microfacies association, coupled with statistical data derived from foraminifera. The first approach has been introduced and described by many authors, (e.g. 28, 68-71, and others). The microscopic 
investigation of the microfacies revealed the presence of two microfacies each one characteristic and of common occurrence in each of the two members.

The Campanian microfacies reveal the dominance of the fossiliferous mudstone microfacies association, that somewhat resemble pelagic wackstone and was most probably deposited in the deep basin margin. On the other hand, the Maastrichtian sediments are characterized here by the presence of foraminiferal micrite (wackstone),
The deep water planktonic habitats are dominated by keeled globotruncanids [72]. In the studied material, the planoconvex morphotypes of Globotruncanita spp., Gansserina gansseri, Globotruncana spp. dominate the Maastrichtian faunas.

The agglutinated benthonic foraminifera are low in abundance and dominated by large-sized Gaudryina, Tritaxia, and Dorothia. The presence of the genus Bolivinoides indicates warm water and open marine condition [73-75]. The dominance of

\begin{tabular}{|c|c|c|c|c|c|c|c|}
\hline Time Unit & Rock Unit & $\underset{\#}{\text { Sample }}$ & Plankt. & $\begin{array}{c}\text { Benth. } \\
\%\end{array}$ & $\begin{array}{l}\mathrm{P} / \mathrm{B} \\
\text { ratio }\end{array}$ & Paleodepth (m) & $\begin{array}{c}\text { TOC } \\
\text { Wt \% }\end{array}$ \\
\hline & & 41 & 86.5 & 13.5 & 6.40 & 776.23 & 3.9 \\
\hline & & 40 & 80.6 & 19.4 & 4.15 & 631.64 & 3.1 \\
\hline & & 39 & 70.7 & 29.3 & 2.41 & 447.53 & 2.3 \\
\hline & & 38 & 68.8 & 31.2 & 2.20 & 418.99 & 2.1 \\
\hline
\end{tabular}

Table 2 Statistical data representing the quantitative analysis of Sudr Chalk in G. El Bruk, North Sinai.

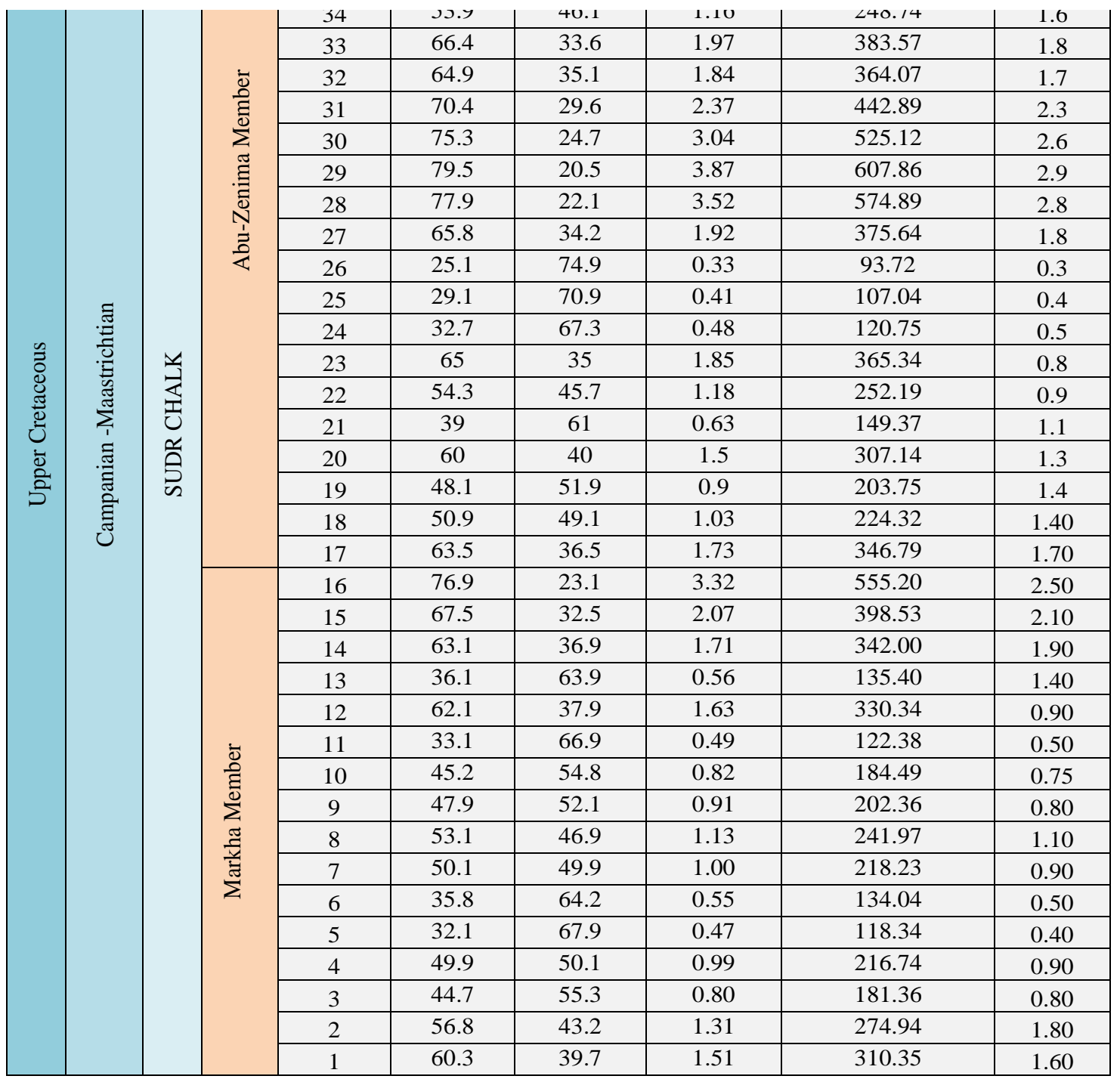

similar to pelagic wackstones deposited in basin margin or deep shelf margin but respectively deeper than fossiliferous mudstone (Fig. 7). A close inspection of the foraminiferal parameters revealed the following clues.
Coryphostoma incrassata (Reuss) in this unit indicates an middle neritic environment [58]

Abdel Kireem [76] suggested an outer-shelf depth for the middle part of the Chalk Formation (Maastrichtian) of the Bahariya Oasis. El-Nady [64] 
suggested middle to outer shelf (100-200m depth) for the Abu Zenima Member of the Sudr Chalk, in northeastern Sinai. Abdel Kireem et al. [47] considered that the upper part of the Khoman Formation (Sudr Chalk equivalent) of the Northern Western Desert to be deposited in the middle slope (>600m depth).

The faunal group in the studied sections is correlated with both the Midway fauna type (MF) and Velasco fauna type (VF) of the gulf coastal plain of Texas and upper lizard spring of Mexico respectively [55]. The Upper Cretaceous sediments in the study area exhibit a close affinity with the Midway-Velasco fauna. Therefore, the calculated ratios between both allow a full calibration of the faunas among these provinces. It is observed that the Campanian Sudr Chalk (Markha member) mostly exhibits Midwayan-type fauna such as Anomalinoides acutus, Cibicidoides alleni, Lenticulina isidis and Cibicides beamountianus, whereas most of Velasco-type fauna sporadically occurred with low diversity. Among the recorded Velascoan-fauna are: Bolivinoides draco doreeni, Gavelinella clementiana, Stensioena excolata and Eponides plummerae. The Maastrichtian Abu- Zenima member shows a different relationship between the two groups, while the dominance of Midway is noticed in the Campanian, The Maastrichtian shows the mixed nature of Midwayan-Velascoan fauna which exhibit depth range from ca. $500 \mathrm{~m}$ [77]. It is believed that the tectonic and depositional setting of the Velasco fauna type may produce a mixed faunal assemblage [78]. This is observed here for the late Maastrichtian, where the sea level underwent progressive transgression from the later part of CF4a up to CF2.

It is standard procedure in many regional studies to compare the interpreted regional sea-level cycles with the eustatic model published by Haq et al. [81]. However, today many stratigraphic intervals covered by the Exxon-curve, especially for the Late the concept of a single global eustatic curve it may be better in most cases to consider several regional curves [85].

The construction of paleobathymetry in the study area is calculated using the empirical equation of De Rijk et al. [86] and depends upon PI \%

$$
\mathrm{D}=\mathrm{e}\{(\% \mathrm{pl}+81.9 / 24)\}
$$

The resultant sea level curve (Fig.6) matched with the global sea level of Haq et al. [81] and the sea level curve of Lüning et al. [85] in G. Arief el- Naga. It is observed that, some intervals correspond with the global one spanning from CF6 and the early part of CF4 in addition to full CF2 Zone. The rest of curve might be biased by the higher resolution of the current biostratigraphic zonation, in addition to sea level fluctuations from tectonic instability due to the Syrian arc system from Middle Campanian and upward.

\section{Hydrocarbon Potential}

Although the richness of organic carbon is usually associated with shale or silty shale, the upper Cretaceous carbonate deposits have been identified for a long time as a source rock? for the overlying petroleum and gas reservoirs in the petroliferous Gulf of Suez area [87] as well as the Northern Sinai, Nile Delta and Mediterranean offshore areas [23 and 88].

Total organic carbon represents the weight percent of organic matter fraction contaminated within the rock during sedimentation processes that is ultimately being influenced by both initial biomass production and subsequent degree of preservation. Organic matter appears to accumulate significantly in the mudstone and laminated or thin-bedded limestone. Total organic carbon concentration often varies through the sedimentary sequence, indicating changes in sedimentary conditions [89]. A value of

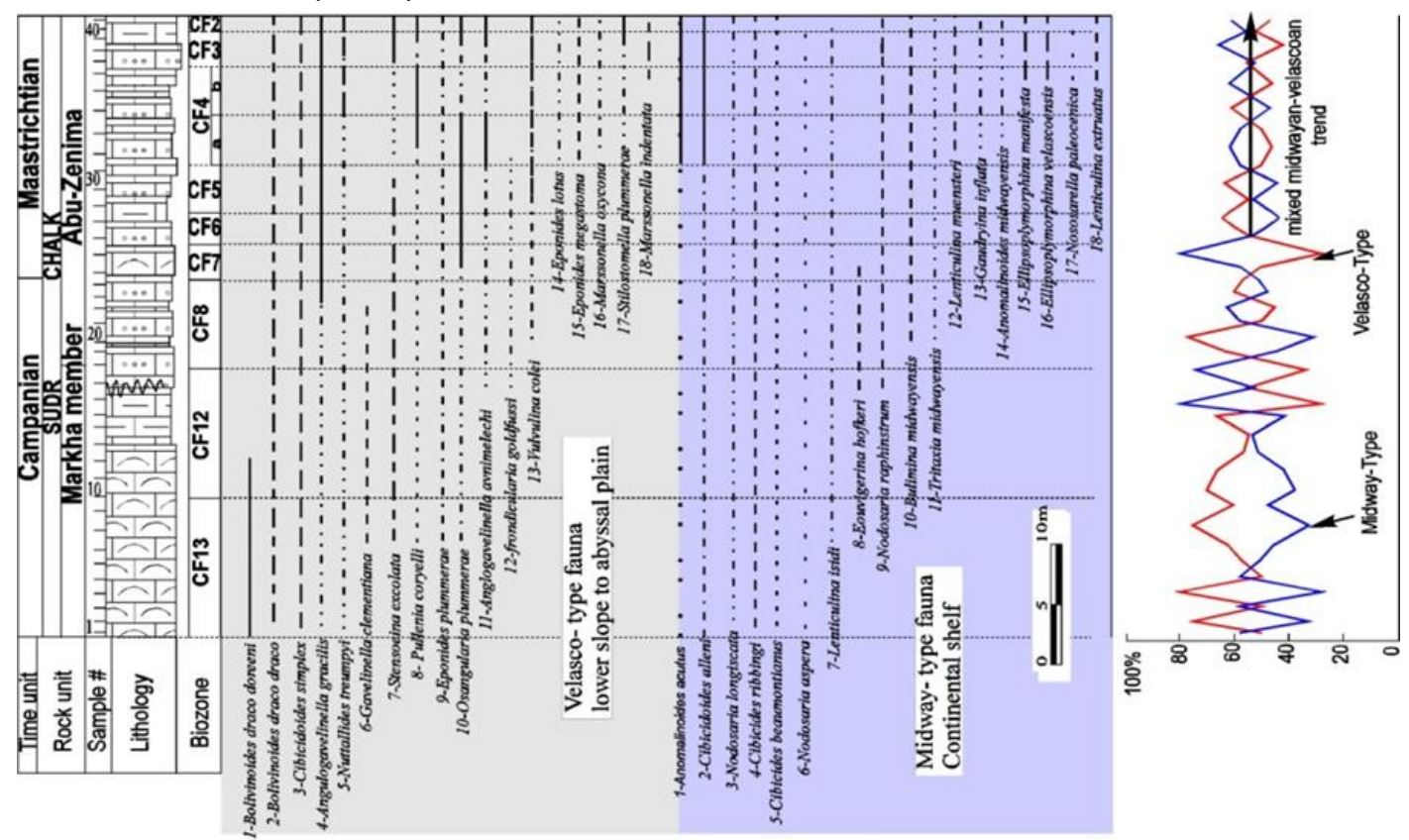

Cretaceous, are questioned to some degree (see 82, 83 and 84]. Because of the apparent restrictions of

approximately $0.5 \%$ total organic carbon by weight 


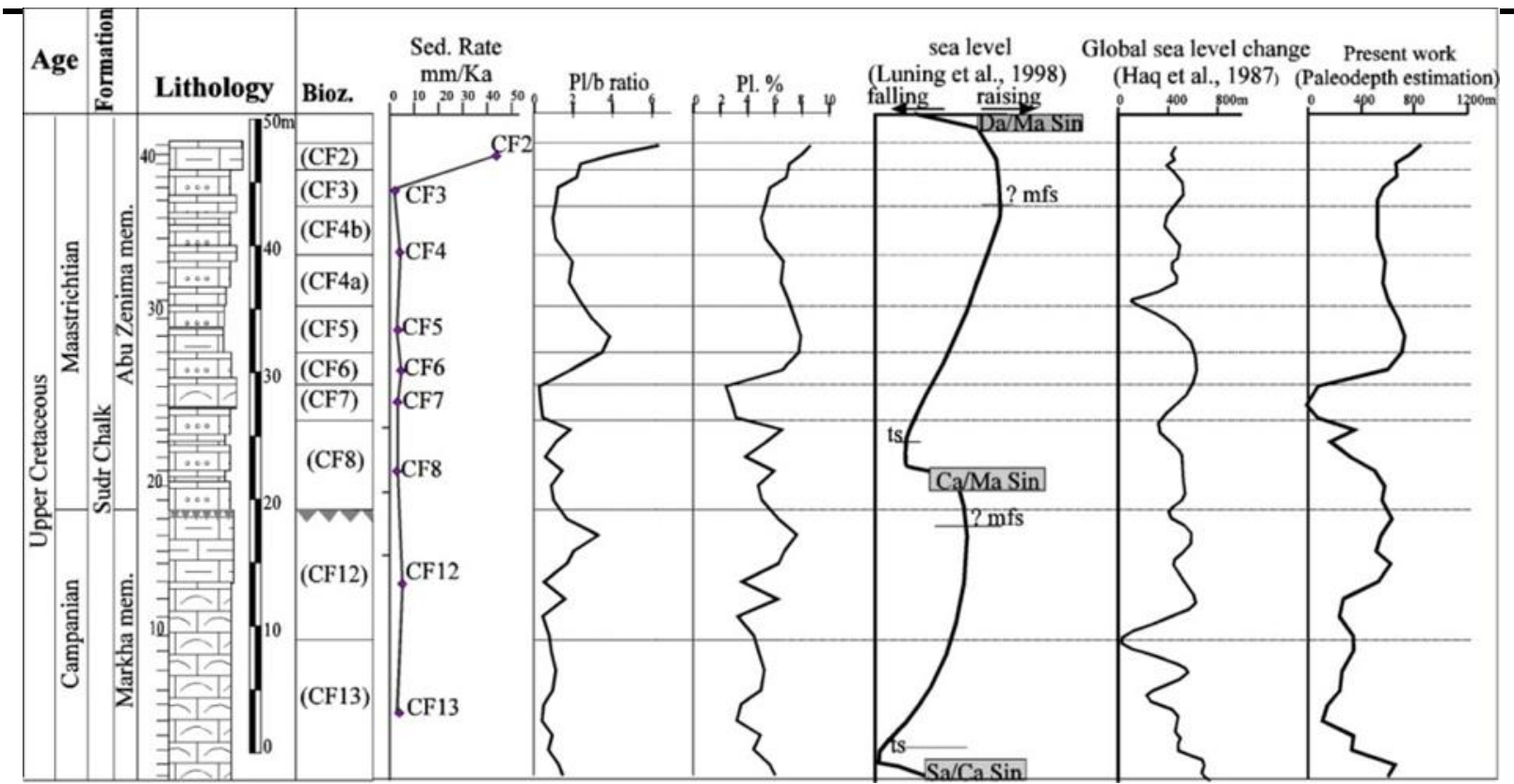

percent is considered the minimum for an effective

3-There are three intervals of maximum TOC source rock, within the studied Sudr Chalk which indicates a fair

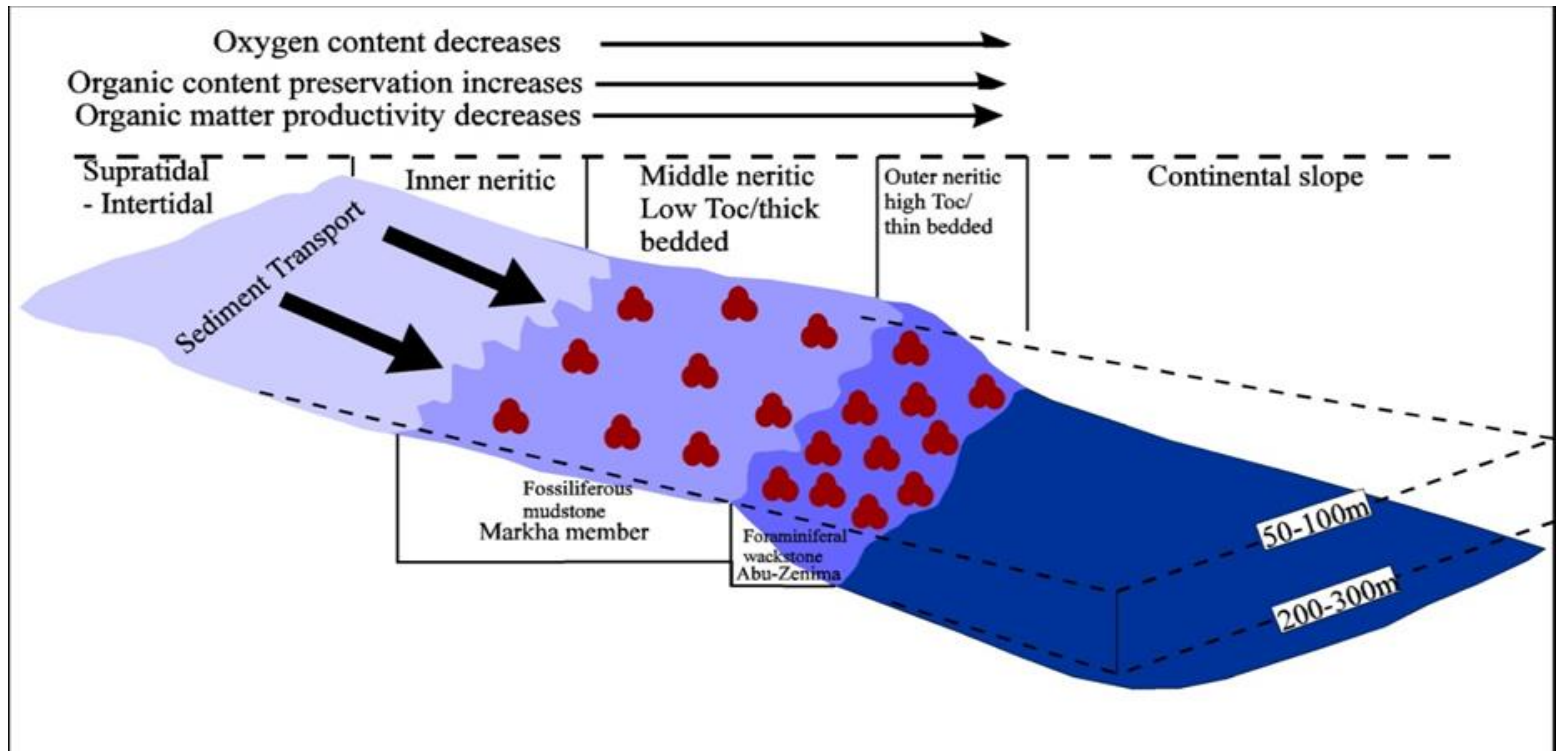

In this study, the complete data analysis of TOC measurements that have been done on forty-one Figure 6 Schematic diagram showing the depositional environment suggested for Sudr Chalk according to the findings of current work and semi-quantitative foraminiferal analyses versus the lithostratigraphic and biostratigraphic section of the Upper Cretaceous Sudr Chalk in Gabal El-Bruk, North Sinai

sample shows a wide variation of TOC content ranging between 0 and 4.5 weight $\%$ (Table 1 ). The features of this variation can be summarized as follows:

1-The TOC of Markha Member ranges between $0.4 \%$ and $2.1 \%$ with $1.18 \%$ average for the whole member, whereas the TOC for Abu-Zenima Member ranges between $0.3 \%$ and $4.5 \%$ weight, with an average $1.99 \%$ for the whole member (Figure 8 ).

2-The TOC appears to accumulate significantly within the well laminated Abu Zenima Member than within the massive chalk of Markha Member. Thus, the bed thickness of Sudr Chalk reveals an inverse proportion to the TOC content, where by the thinner the bed thickness of Sudr Chalk, the higher the TOC content (Figure 8). planktonic foraminifera as well as the $\mathrm{Pl} / \mathrm{b}$ ratio.

The TOC content shows a remarkable increase in the outer shelf chalky limestone of the Abu Zenima Member rather than the shallow middle shelf depositional environment suggested for the Campanian Markha Member.

The TOC richness depends mainly on the organic matter productivity and preservation processes. The productivity processes are closely related to the bloom of micro-organisms [90] that alternatively controlled by nutrition inputs, depositional energy conditions, and ecological environment. The relationship between organic carbon content and sedimentation rate has been used to get rough estimates of paleoproductivity where the lowproductivity environments are characterized by low organic carbon contents (< $0.4 \%)$ and low 
sedimentation rates $(0.2-1 \mathrm{~cm} / 1000$ years) (Fig. 6), whereas the high-productivity upwelling environments are characterized by very high organic carbon contents (up to 20\%) and very high sedimentation rates (up to some $100 \mathrm{~cm} / 1000$ y.). In the current work, sedimentation rate has been calculated by dividing the thickness of sediments defined by its biozone on the time consumed in deposition. Sedimentation rate (SR) of the Sudr chalk reveals an expected low value that varies between 1.4 to $5.4 \mathrm{~mm} / 100 \mathrm{Ky}$ with an exceptional interval of high SR $(40 \mathrm{~mm} / 100 \mathrm{ky})$ associated with the biozone CF2 that has higher TOC content. These sediments were accumulated in a highly productive upwelling regime that dominated the southern Tethys margin from the Santonian to Late Maastrichtian [91, 92, 93, 94 and 20].

On the other hand, the preservation process is controlled by sedimentation rate, oxic to anoxic conditions, and diagenesis [95]. In the studied Sudr Chalk, the role of the productivity process in TOC richness is highly evidenced by the abundance of planktonic foraminifera species and the high P:B ratio. On the other hand, the preservation process of organic matter in Sudr Chalk is more likely to be affected by the lithological variation from the Chalk of Markha member to the argillaceous chalky limestone of the Abu Zenima Member. The redox condition of the deeper, low energy depositional environment of $\mathrm{Abu}$ Zenima resulted clearly in richness of TOC. Accordingly, the low TOC intervals of Sudr Chalk are interpreted as zones of relatively shallower, high energy and oxic conditions of shallow-middle shelf environments, where the clastic dilution of organic matter is very common as well as the higher influence of biodegradation processes.

\section{Conflicts of interest}

"There are no conflicts to declare".

\section{References}

[1] Krenkel, E., 1924: Der syrische Bogen. Centralblatt für Mineralogie, Geologie und Paläontologie, Abhandlungen, B9: 274-281; 10: 301-313.

[2] Ghorab, M. A., 1961: Abnormal stratigraphic features in Ras Gharib oil field (in Arabic). 3rd Arab.Petrol.Congr., $10 \mathrm{pp}$.

[3] Ansary, S.E. \& Tewfik, N.M., 1969: Biostratigraphy and time stratigraphy of subsurface Upper Cretaceous of Ezz El Orban Area, Gulf of Suez Region, U.A.R. -Proc. 3rd Afric. Coll. Micropaleont.: 95-106.

[4] Lüning, S., Marzouk, A. M., Morsi, A. M., and Kuss, J., 1997: Sequence stratigraphy of the Upper Cretaceous of central east Sinai, Egypt: Cretaceous Research, v. 19, p. 153-196.

[5] Akarish, Al. M., 1999: Microfacies analysis of the Cenomanian- Paleocene exposures of TabaNuweiba area, East Sinai: Middle East Research
Centre, Ain Shams University, Cairo, Earth Science Series, v. 13, p. 135-152.

[6] Ismail, A.A., 2000: Upper Cretaceous stratigraphy and micropaleontology of the western part of the Gulf of Aqaba, East Sinai, Egypt: Middle East Research Centre, Ain Shams University, Cairo, Earth Science Series, 14, p. 239-261.

[7] Shahin, A. \& El Nady, H., 2001: planktonic foraminiferal biostratigraphy and paleobathymetry of the Late Cretaceous-Early Tertiary succession at northeast Sinai, Egypt. Egyptian Journal of Paleontology, 1:193-227.

[8] Samir, A. M., 2002: Biostratigraphy and paleoenvironmental changes in the Upper Cretaceous-Early Paleogene deposits of Gebel Samra section, southwestern Sinai, Egypt.Egyptian Journal of Paleontology, 2:1-40

[9] El Nady, H., 2006: Contribution to the stratigraphic significance of the Genus Bolivinoides and their paleoecology across the Campanian / Maastrichtian boundary in the Gabal El-Mouriefik section, Eastern Sinai, Egypt.- Revue Paléobiologie, Genève, 25/2: 671-692.

[10] Samuel, M.D., Ismail, A.A., Akarish, A.I.M. and Zaky, A.H., 2009: Upper Cretaceous stratigraphy of the Gebel Somar area, north-central Sinai, Egypt. Cretaceous Research, 30: 22-34.

[11] Ismail, A., 2012: Late Cretaceous-Early Eocene benthic foraminifera from Esh El Mallaha area, Egypt.- Revue de Paléobiologie, 31/1: 15-50.

[12] Ansary, S.E., Andrawis, S.F. and Fahmy, S. E., 1962: Biostratigraphic studies of the Upper Cretaceous section in the G.P.C. Wells in the Eastern Desert and Sinai. 4th Arab.Petrol.Congr. Paper No. 24 (B-3): 339-354.

[13] Ansary, S.E. \& Emara, M.M., 1962: A New Foraminiferal Fauna from El Minshera Area, North Sinai. -J. Geol. U.A.R., 6/2: 85-101.

[14] Ansary, S.E. \& Tewfik, N.M., 1966: Planktonic Foraminifera and some new benthonic Species from the Subsurface Upper Cretaceous of Ezz EI Orban, Gulf of Suez. -J. Geol. U.A.R., 10/1: 37-76.

[15] Awad, G. H. \&Abdallah, A. M., 1966: Upper Cretaceous in Southern Galala, Eastern Desert, with emphasis on neighbouring areas.- Egypt. J. Geol., 10/2: 125-144.

[16] El Shinnawi, M.A., 1967: Contribution to the stratigraphy of the white Chalk Formation at WadiSudr, Western Sinai, U.A.R. -Bull. Fac. Sci., Alexandria Univ., 8: 199-217.

[17] Andrawis, S., 1967: Biostratigraphic studies of the Subsurface Paleocene sections of Ezz El Orban-Ras El Behar Region in the Western coast of Gulf of Suez. -6th Arab. Petro.Congr.Paper No. 2(B-3), $4 \mathrm{pp}$.

[18] Bartov, Y. \& Steinitz, G., 1977: The Judea and Mount Scopus groups in the Negev and Sinai with trend surface analysis of the thickness data- Israel J. Earth Sci., 26: 119-148.

[19] Ziko, A., Darwish, M. and Eweda, S. 1993: Late Cretaceous- Early Tertiary stratigraphy of the Themed area, East Central Sinai, Egypt. -Neues 
Jahrbuch Geologie Palaontologie Monatshefte 3, 135-I 49.

[20] Lüning, S., Marzouk, A.M. and Kuss, J. 1998a: Late Maastrichtian litho and ecocycles from hemipelagic deposits of eastern Sinai, Egypt.-. Journal of African Earth Sciences, 27: 373-395.

[21] Cherif, O.H., Al Rifaiy, I.A., Al Afifi, F.I. and Orabi, O.H., 1989: Planktonic Foraminifera and chronosrtatigraphy of Senonian exposures in west-central Sinai, Egypt. -Revue de Micropaleont., 32/3: 167-184.

[22] Shahin, A.M., 1992: Contribution to the foraminiferal biostratigraphy and paleobathymetry of the Late Cretaceous and Early Tertiary in West Central Sinai, Egypt.-Rev. Micropaléont., 35/2: 157-175.

[23] Alsharhan, A. S. \& Salah, M. G. 1996: Geologic setting and hydrocarbon potential of north Sinai, Egypt. Bulletin of Canadian Petroleum Geology 44: 615-631.

[24] Abdin, S. and Aal, A. 1992. Impact of oil exploration on Sinai development.3rd Conference on Sinai Development Ismailia. V. 1, p .281-288.

[25] Aal, A.A., and Lelek, J. J. 1994. Structural development of the northern Sinai, Egypt and its implication on the hydrocarbon prospectively of the Mesozoic. GEO 94, the Middle East Geosciences Conference Bahrain, V .I, p. 15-30.

[26] Tarnmam, M.T. 1994. Oil window and source rock of north Sinai province. 12th EGPC Exploration Seminar, Egypt, v. 2, p. 175-197.

[27] Dunham, RJ., 1962: Classification of carbonate rocks according to depositional texture: American Association Petroleum Geologists Bulletin, 1:108121.

[28] Wilson, J. L., 1975: Carbonate facies in geological history.- Springer Verlag; Berlin, $471 \mathrm{p}$.

[29] Flügel, E., 2004: Microfacies of carbonat rocks. Springer- Verlag, Berlin-Heidelberg-New York, $976 \mathrm{p}$.

[30] Schumacher, B.A., 2002: Methods for the determination of total organic carbon (TOC) in soils and sediments.- Ecological Risk Assessment Support Center, Office of Research and Development.US Environmental Protection Agency., NV. 25p.

[31] Ben-Dor, E. \& A. Banin, 1989: Determination of organic matter content in arid zone soils using asimple Loss-On-Ignition method. -Commun.in Soil Sci and Plant Anal. 20: 1675-1695.

[32] Ghorab, M.A., 1956: A summary of a proposed rock stratigraphic classification for the Upper Cretaceous rocks in Egypt. Geological Society of Egypt. (unpublished).

[33] Kerdany, M. T. \& Cherif, O. H. 1990: Mesozoic. In "The geology of Egypt" (ed. Said, R.), pp. 407-438 (Balkema, Rotterdam).

[34] Malchus, N. 1990: Revision der Kreide-Austern (Bivalvia: Pteriomorphia) Agyptens (Biostratigraphie, Systematik). Berliner Geowissenschaftliche Abhandlungen, A 125.

[35] Kora, M. \& Genedi, A. 1995: Lithostratigraphy and facies development of the Upper Cretaceous carbonates in east central Sinai, Egypt. Facies 32: 223-236

[36] Refaat, A. A. A. 1993: Facies development of the Coniacian-Santonian sediments along the Gulf of Suez, Egypt. Berliner Geowissenschaftliche Abhandlungen A 150, 146 pp.

[37] Orabi, O. H. \& Ramadan, F. S., 1995: Contribution to the stratigraphy and microfacies of the Matulla Formation in southern Wadi Feiran and Wadi Abuira, west-central Sinai, Egypt. Egyptian Journal of Geology 39: 339-360.

[38] Bathurst, R. G., 1972: Carbonate sediments and their diagenesis. New York, American Elsevier Co., $700 \mathrm{pp}$.

[39] Li, L. \& Keller, G., I998a: Maastrichtian climate, productivity and faunal turnovers in planktic foraminifera in South Atlantic DSDP Sites 525A and 21. Marine Micropaleontology, 33: 55-86.

[40] Li, L. \& Keller, G., 1998b: Diversification and extinction in Campanian-Maastrichtian planktic foraminifera of northwestern Tunisia. Eclogae Geol. Helv., 91: 75-102

[41] Li, L., Keller, G. and Stinnesbeck, W., 1999: The Late Campanian and Maastrichtian in Northwestern Tunisia: palaeoenvironmental inferences from lithology, macrofauna and benthic foraminifera. Cretaceous Research 20: 231-252.

[42] Hassan, H. F. \& Nassif, M.S., 2010: CampanianMaastrichtian planktonic Foraminiferal biostratigraphy and Paleoclimatic changes in North Sinai , Egypt.- 5th Int. Conf. Geo. Tethys Real., 403-420

[43] Farouk, S. \& Faris, M., 2008: Campanian to Eocene planktic foraminiferal and calcareous nannofossil biostratigraphy in the synclinal areas around Gebel Libni, North Sinai, Egypt. - Middle East Research Center, Ain Shams University, 22, 187-201.

[44] Farouk, S. \& Faris, M., 2012: Late Cretaceous calcareous nannofossil and planktonic foraminiferalbioevents of the shallow-marine carbonate platform in the Mitla Pass, west central Sinai, Egypt- Cretaceous Research 33, 50-65.

[45] Stehli, F.G \&Creath, W.B., 1964: Foraminiferal ratios and regional environments. Bulletin. American Association of Petroleum Geology, 48: 1810-1827.

[46] Murray, W.J. \& Wright, C. A., 1974: Paleogene foraminiferida and paleoecology, Hampshire and Paris Basins and the English Channel.- The Paleontological association, London, Spec. Pap. in paleontology No. 14: 1-129.

[47] Abdel-Kireem, M. R., Schrank, E., Samir, A.M. and Ibrahim, M. I. A., 1996: Cretaceous paleoecology, paleoclimatology and paleogeography of the northern Western Desert, Egypt.-J. Afric. Earth Sci., 22/1: 93-112.

[48] Gibson, T. G., 1988: Assemblage characteristics of modern benthic Foraminifera and application to environmental interpretation of Cenozoic deposits of eastern North America.- Rev. Paleobiol., 2: 777-787. 
[49] Jones, R.W., \& Charnock, M. 1985:'Morphogroups' of agglutinating foraminifera. Their life positions and feeding habitats and potential applicability in (palaeo)ecological studies.- Revue de Paléobiologie, 4: 311-320.

[50] Corliss, B. H. \& C. Chen, 1988: Morphotype pattern of Norwegian Sea, deep sea benthic foraminifera and ecological implications : Geology, 16: 716-719.

[51] Koutsoukos, E.A.M. \& Hart, M.B., 1990: Cretaceous foraminifera morphogroup distribution patterns, palaeo communities and trophic structures: a case study from the Sergipe Basin, Brazil. Transactions of the Royal Society of Edinburgh: Earth Sciences, 81:221-246.

[52] Sliter, W. V. \& Baker, R. A., 1972: Cretaceous bathymetric distribution of benthic foraminifera.J. Foram. Res., 2/4: 167-183.

[53] Berggren, W. A., 1974a: Late Paleocene-Early Eocene benthonic foraminiferal biostratigraphy and paleoecology of Rockall Bank.Micropaleontology, 20/4: 426- 448.

[54] Berggren, W. A., 1974b: Paleocene benthonic foraminiferal biostratigraphy, biogeography and paleoecology of Libya and Mali.Micropaleontology, 20/4: 449-465.

[55] Berggren, W.A. \& Aubert, J., 1975: Paleocene benthonic foraminiferal biostratigraphy, paleobiogeography and paleoecology of AtlanticTethyan regions: Midway type fauna. Paleogeogr., Paleoclimatol. Paleoecol., 18: 73 192.

[56] Berggren, W.A. \& Aubert, J., 1983: Paleocene benthonic foraminiferal biostratigraphy and bathymetry of the central coastal ranges of California. -In: BRABB, Earl E. (ed): Studies in Tertiary stratigraphy of the California Coast Ranges. -U.S. Geol. Surv. Prof. Paper, 1213: 4-21.

[57] Aubert, J. \& Berggren, W.A., 1976: Paleocene benthonic foraminiferal biostratigraphy and paleoecology of Tunisia. -Bull. Centr. Res. Pau SNPA, 10: 379-469.

[58] Olsson, R. K. \& Nyong, E. E., 1984: A paleoslope model for Campanian- Lower Maastrichtian foraminifera of New Jersey and Delaware.- J. Foram. Res., 14/1: 50- 68

[59] Morkhoven, F. P.C.M. Van, Berggren, W.A. and Edwards, A. S., 1986: Cenozoic cosmopolitan deep-water benthic foraminifera. Bull. Centre Resh. Explor.- Prod. Elf-Aquitaine, Mem., 11: 1421.

[60] Saint-Marc, P. \& Berggren, W. A., 1988: A quantitative analysis of Paleocene benthic foraminiferal assemblage in Central Tunisia.- J. Foram. Res., 18/2: 97-113.

[61] Luger, P., 1985: Stratigraphie der marinen Oberkreide und des Alttertiurs in südwestlichen Obernilbecken (SW-Agypten) unterbesonderer Berücksichtigung der mikropaleontologie, palokologie und paleogeographie.- Berliner geowiss. Abh., A-63, 151 pp.
[62] El-Dawy, M.H., Azab, M. and Dakrory, M. A., 1992: Biostratigraphy and paleoecology of the Upper Cretaceous- Lower Tertiary in Gabal Sahaba, northwest Sinai.- Proc.3rd Conf. Geol. Sinai Develop., 3: 175-190.

[63] Anan, H.S., 1992: Maastrichtian to Ypresian stratigraphy of Abu Zenima section, west central Sinai, Egypt. -M.E.R.C. Ain Shams Univ., Earth Sc. Ser., 6: 62-68.

[64] El-Nady, H. I. A., 1995: Biostratigraphy of the Upper Cretaceous-Lower Tertiary successions in Northern Sinai, Egypt.-Unpublished Ph.D. Thesis, Geol. Depart., Fac. Sci., Mansoura Univ., 350 pp.

[65] Bé, A.W.H., 1977: An ecological, zoogeographic and taxonomic review of recent planktonic foraminifera, in Ramsay, A.T.S. (ed.), Oceanic Micropaleontology, : 1-100.

[66] Douglas, R. G., \& Savin, S. M., 1978: Oxygen isotopic evidence for the depth stratification of Tertiary and Cretaceous planktonic foraminifera. Mar. Micropaleontol. 3:175-196.

[67] Hart, M. B., 1980: A water depth model for the evolution of the planktonic foraminifera.- Nature, 286: 252- 254.

[68] Reading, H.G. (ed.), 1982: Sedimentary environments and facies. Blackwell, Oxford, 557 pp.

[69] Flügel, E., 1982: Microfacies analysis of limestones. Springer- Verlag, Berlin-HeidelbergNew York, $633 \mathrm{p}$

[70] Reeckmann, A. \& Friedman, G.W., 1982: Exploration for carbonate petroleum reservoirs.J. Wiley and Sons, Chichester, 213 pp.

[71] Selley, R. C., 1985: Ancient Sedimentary Environment, third ed. Cornell University Press, $317 p$.

[72] Leckie, R.M., 1987: Paleoecology of midCretaceous planktonic foraminifera: A comparison of open ocean and epicontinental sea assemblages: Micropaleontology, 33: 264-276.

[73] Barr, F.T., 1970: The foraminiferal Genus Bolivinoides from the Upper Cretaceous of Libya. -J. Paleont. 4/4: 642-654.

[74] Barr, F.T., 1972: Cretaceous biostratigraphy and planktonic foraminifera of Libya. -Micropaleont. 18/1: 1-46.

[75] Premoli-Silva, I. \& Bolli, H.M., 1973: Late Cretaceous to Paleocene foraminifera and stratigraphy of LEG 15 sites in the Caribbean sea. -Initial Reports DSDP, 15: 499-547.

[76] Abdel-Kireem, M. R., 1986: Microfaunistic parameters of the chalk Formations (Upper Cretaceous), Bahariya Oasis, Egypt. Revista Espanola De Micropaleontologia, XVIII/1: 27-46.

[77] Speijer, R. P. 1994: Extinction and recovery patterns in benthic foraminiferal paleocommunities across the Cretaceous/Paleogene and the Paleogene/Eocene boundaries. Geological Ultraiectina 124, $191 \mathrm{pp}$.

[78] Fluegeman, R. H., 1999: Preliminary study of the benthic foraminifera of the San Francisco de Paula Section (Upper Paleocene-Lower Eocene), 
Ciudad de la Habana, Cuba: Micropaleontology, 45: 43-56.

[79] Speijer, R.P., van der Zwaan, G.J. and Schmitz, B., 1996: The impact of Paleocene/Eocene boundary events on middle neritic benthic foraminiferal assemblages from Egypt. Marine Micropaleontology, 28: 99-132.

[80] Speijer, R.P. \& Schmitz, B., 1998: A benthic foraminiferal record of Paleocene sea level and trophic/redox conditions at Gebel Aweina, Egypt. Palaeogeography, Palaeoclimatology Palaeoecology, 137:79-101.

[81] Haq, B.U., Hardenbol, J., and Vail, P.R., 1987. Chronology of fluctuating sea levels since the Triassic (250 million years ago to present). Science, 235: 1156-1167.

[82] Hancock, J. M. 1989: Sea-level changes in the British region during the late Cretaceous. Proceedings of the Geologists' Association, 100:565-594.

[83] Miall, A.D., 1991: Stratigraphic sequences and their chronostratigraphic correlation. J. Sediment. Petrol. 61, 497-505.

[84] Miall, A.D., 1992: Exxon global cycle chart: an event for every occasion. Geology 20, 787-790.

[85] Lüning, S., Kuss, J., Bachmann, M., Marzouk, A.M.and Morsi, A.M., 1998b: Sedimentary response to basin inversion: Mid Cretaceous Early Tertiary pre- to syn-deformational deposition at the Areif El Naqa anticline (Sinai, Egypt). Facies 38: 103-136.

[86] De Rijk, S., Troelstra, S. R., and Rohling, E. J., 1999. Benthic foraminiferal distribution in the Mediterranean Sea. Journal of Foraminiferal Research, 29: 93-103.

[87] Sestini, G. 1995: AÈ gypten. In Regional petroleum geology of the world, Part II (ed. Kulke, H.), Beitragezur Regionalen Geologie der Erde 22, pp. 57-87 (Gebru Èder Borntraeger, Stuttgart).

[88] Dolson, J.C., M.V. Shann, S. Matbouly, C. Harwood, R. Rashed, and H. Hammouda, 2001: The petroleum potential of Egypt, in Petroleum Provinces of the Twenty-first Century, AAPG Memoir 74: 453-482.

[89] Meyers, W. J., \& K. C. Lohmann, 1985: Isotope geochemistry of regionally extensive calcite cement zones and marine components in Mississippian limestones, New Mexico, in P. M. Harris, and N. Schneidermann, eds., Carbonate Cements, Tulsa,OK, SEPM Special Publication No. 36: 223-239.

[90] Pedersen, T.F. \& Calvert, S.E., 1990: Anoxia vs productivity: What controls the formation of organic-carbon-rich sediments and sedimentary rocks? AAPG. Bulletin, 74: 454-466.

[91] Reiss, Z. 1988. Assemblages from a Senonian high productivity sea. Revue Paleobiolgie, Volume Speciale 2 (Benthos '86). 323-332.

[92] Shemesh, A. and Kolodny, Y. 1988: Oxygen isotope variations in phosphorites from the southeastern Tethys. Israel Journal Earth Sciences 37: I-1 5 .
[93] Almogi-Labin, A., Bein, A. and Sass, E. 1993: Late Cretaceous upwelling systems along the southern Tethys margin (Israel): interrelationships between productivity, bottom water environments, and organic matter preservation. Paleoceanography 8: 671-690.

[94] Eshet, Y., Almogi-Labin, A. and Bein, A. 1994: Dinoflagellate cysts, paleoproductivity and upwelling systems: A Late Cretaceous example from Israel. Marine Micropaleontology , 23: 231 240.

[95] Demaison, G. J., \& Moore, G. T., 1980: Anoxic environments and oil source bed genesis. Org. Geochem., 2:9-31. 